\title{
Average Collection Period and Financial Performance of Nzoia Water Services Company
}

\author{
Wasike Michael Wafula ${ }^{1}$, Charles Yugi Tibbs ${ }^{2}$ and Alala Benedict Ondiek ${ }^{3^{*}}$ \\ ${ }^{1,2,3}$ Department of Accounting and Finance Masinde Muliro University of Science and Technology P.O. BOX 190-50100 Kakamega, Kenya
}

Received 01 March 2019, Accepted 02 May 2019, Available online 04 May 2019, Vol.7 (May/June 2019 issue)

\begin{abstract}
Account receivables have been a majo'r problem for most utility service providers especially those still dealing with the post payment method where services are rendered before payment are made. This study sought to find out effect of the average collection period and financial performance. The study obtained secondary data spanning from 2012 to 2016 from Kenya national audit office and Nzoia Water Services Company published financial statements. The study employed explanatory research design and data was collected from secondary data and analyzed using regression and correlation analysis and found the relationship between financial performance. From the findings the mean average collection period was 309.90 days, accounts receivable turnover had a mean of 1.1980 , size of the region (7.5870). The results showed that NZOWASCO, financial performance variable Return on Equity (ROE) was significantly affected with average collection period with negative correlation-0.232. According to the regression equation established, taking all factors into account; Average collection period on financial performance of NZOWASCO measured by ROE was 0.505. The study recommended that the organization reduce average collection period in order to improve their financial performance of the organizations.
\end{abstract}

Keywords: Average Collection Period, Financial Performance

\subsection{Introduction}

Accounts receivable is the money owed to the company as a result of having sold its products to customers on credit (Kontus, 2013). When goods and services are sold under an agreement permitting the customer to pay for them at a later date, the amount due from the customer is recorded as accounts receivables (Joy, 1978); Receivables are asset in accounts representing amounts owed to the firm as a result of the credit sale of goods and services in the ordinary course of business. According to Maksimovic and Demirguc (2001) Accounts receivable constitute $25 \%$ of working capital and therefore care should be taken in their management. Accounts Receivable management includes establishing a credit and collection policy. Credit policy consists of four variables namely credit period, discount given for early payment, credit standards and collection policy. The three primary issues in Accounts Receivable management are to whom credit should be extended, the terms of the credit and the procedure that should be used to collect the money (Kontus, 2013).

*Corresponding author's ORCID ID: 0000-0002-7802-8383

DOI: https://doi.org/10.14741/ijmcr/v.7.3.5
Liquidity and profitability are the two important measures of financial performance. Liquidity measures the ability of a company to honor and meet all its maturing obligations. Profitability is the rate of return on company's investment (Panwala, 2009). All this can be attained by better management of accounts receivable. The efficient management of accounts receivable ensures the survival, liquidity, solvency and profitability of a business organization (Ansah, 2011). An organization which practices proper management of accounts receivable would be liquid and would be able to meet its short term obligation as they arise.

Nzoia Water Services Company bills its customers on credit and it takes four to five weeks to distribute invoices to customers and six to eight weeks to claim its money. According to Pandey (2008), average collection period determines the speed of payment by customers and delayed payment is a potential ground for bad debts which have a negative effect on a firm's financial performance. According to WASREB (2011) the debtors' days ratio indicates how quickly cash is being collected from debtors. The debtors conversion period in days for WSP range from 200 to 250 days (WASREB, 2011).

Accounts receivable is of importance to any organization which had to attain its objective of profit 
maximization. Companies that were able to manage their accounts receivable well would not need to borrow funds from outside and can be able to sustain themselves.

According to Backman (1962), trade receivables relate to selling of goods and services on credit. It needs efficient management since there are risks, related to the future and has greater economic value. Risks faced are in terms of default in the future since the amount is collectable at future date and economic value since there is exchange of goods at monetary value. Trade receivable is considered the third class of assets after plant, property and equipment and inventory and second in class in terms of current assets after inventory. In terms of working capital management, it is considered critical after cash and inventory. Efficient credit policy should be instituted by firms to boost profitability and liquidity levels. For a firm to achieve maximum management of trade receivables, it needs to consider the following factors:- volume in terms of credit trade, pattern of payment by customers, practices and policies in place for management of credit sales, collection policies and terms and conditions for granting credit.

To remain profitable, businesses must ensure proper management of their accounts receivable to avoid finding their liquidity under considerable strain and to remain profitable (Foulks, 2005). Receivables are large investments in firm assets which are like capital budgeting projects measured in terms of their net present value. Receivables stimulate sales because it allows customers to assess product quality before paying but on the other hand, debtors involve funds which are an opportunity costs. Extending credit to customers is a decision based on the credit management and policy of a firm. Granting credit exists to facilitate sales. Al-Mwala (2012) stated that sales are pointless without due payment and therefore the sales and accounts receivable functions must work together to achieve the objective of sales maximization within minimum length of time. Obida and Owolabi (2012) noted that credit sales are signs that a firm is able to maximize its sales and improve its financial performance. An increase in the level of accounts receivables in a firm increases both the net working capital and the cost of holding and managing accounts receivable and both lead to a decrease in the value of the firm. Firms who pursue an increase in the accounts receivable to an optimal level increase their profitability resulting from the increased sales and market share.

As stated by Gitau, Nyangweno, Mwencha, \& Onchagwa (2014) the purpose of credit control was to ensure that trade debts are recovered early enough before they become uncollectible and a loss to the business.

There are six C's of credit which credit managers should consider when extending credit: character, capacity capital, collateral, condition and contribution as stated by (Kilonzo, Memba, \& Njeru, 2016). They further assert that the six C's helps firms to decrease their default rate as they get to know their customers. Information on the C's can be obtained from several sources including the firm's prior experience with the customers, financial statements from previous years and credit reporting". Credit standards refer to the required financial strength of acceptable credit customers. Based on financial analysis and non -financial data, the credit analyst can determine whether each credit applicant exceeds the credit standard and thus qualifies for credit. Lower credit standards boost sales, but also increase bad debts. The minimum standards to check before a customer is extended credit are: character, capital, capacity, conditions and collateral. The credit period, stipulating how long from the invoice the customer has to pay, and the cash discount together comprise the seller's credit terms. A company's credit terms are usually very similar to that of other companies in its industry.

Collection policy is measured by its toughness or laxity in attempting to collect on slow-paying accounts. A tough policy may speed up collections, by it might also anger customers, causing them to take their business elsewhere. In WSP factoring is not common because of fear of losing customers and eventually sales.

Gill, Bigger and Atnur (2010) States that the main objective of accounts receivable is to reach an optimal balance between cash flow management components. Cash flow management is the process of planning and controlling cash flow both into and out of a business, that is, cash flows within the business and cash balances held by a business at a point in time (Samilogu, 2008). Efficient accounts receivable management affords a firm to improve on its profitability by reducing the transaction costs of rising funds in case of liquidity crisis (Ahmet and Emin, 2012).

\subsection{Statement of the research problem}

According to Water service regulatory board (2011) the debtors' conversion period in days for Water Service Providers range from 200 to 250 days. The average debtor days in 2011 assessment were 220 days. There was an improvement across the board with the average debtor days at 188 days. The average debtor days are however still far from the industry accepted norm of 45 to 60 days (WASREB and WSP, 2015).This shows a longer period of Accounts Receivable collection revealing a poor management of Accounts Receivable in these WSP. Nzoia water Service Company was rated as BB Company and therefore had a $\mathbf{2 5 0}$ days debtors conversion period. The longer debtors conversion period indicates that the company would be illiquid and not able to meet its obligation and operation expenses as they arise.

Accounts receivables management is important to the financial performance of an organization. NZOWASCO is not able to access capital from NSE since it's not listed and it does get little funds from the government and WSB. This shows the limitation of financing from the capital market and short-term bank loans to finance their 
operations. Their financial sustainability and performance depends on proper management of accounts receivable which was their sole revenue source.

The water services sector had for long suffered from poor financial performance. These are problems attributed to poor working capital management measures. There was also an issue of no financial sustainability due to a combination of low tariffs, poor accounts receivable and inefficient billing and collection practices (Schwartz, 2007). The research question was therefore "is the poor financial performance attributed to the poor Accounts Receivable management? "

Prior to the enactment of Water Act 2002, water management was undertaken by the District Water Officers and Municipalities. Netherlands Development Organization (2009) in its report noted that: "Many of these Water Service Providers were not sufficiently professional or commercially oriented, leading to poor financial performance and lack of sustainability.

From the foregoing it was clear that accounts receivable plays a bigger role in the financial performance of WSP who do not access any funds from capital markets. Hence the study seeks to find out the effect of Average Collection Period (ACP) on financial performance of Nzoia water Services Company.

\subsection{Objective of the study}

To examine the effect of Average Collection Period (ACP) on the financial performance of Nzoia Water Services Company

\subsection{Hypothesis}

$\mathrm{H}_{01}$ : There is no significant relationship between Average Collection Period and financial performance of NZOWASCO.

\subsection{Significance of the study}

The study would be of importance to policy makers who make decision regarding account receivable in water sector particularly NZOWASCO and other water companies. It would act as a theoretical review and reference point for academicians undertaking related studies. This finding would help to develop an understanding of best practices in the accounts receivable management and financial practices and techniques of managing accounts receivable. The study would reveal best accounts receivable management Strategies, policies, practice and techniques for NZOWASCO and other water companies.

\subsection{Scope of study}

The study was carried in Nzoia Water Services Company which is situated in Webuye as its head office and covering two counties of Bungoma and Trans Nzoia.
Nzoia Water services Company had four region that is Kitale, Bungoma,Webuye and Kimilili regions. NZOWASCO is under LVNWSB. The study obtained secondary data for a period of five years spanning from 2012-2016 by data sheet administered to KENAO and commercial department at head office and was analyzed using by inferential and descriptive statistical methods to find if there was relationship between accounts receivable management and financial performance.

\subsection{Literature Review}

\subsection{Theoretical review}

\subsection{Price Discrimination theory}

Price discrimination is an act of billing the same product to different clients with different prices, even when the costs of supplying them are same. This practice was mostly observed by monopolists as they exploit their leading power for discrimination. NZOWASCO practice this theory by classifying their customers into categories of domestic consumers, Schools and institutions, Commercial and Government of which they bill them differently for same water provision.

Price discrimination occurs when a firm sells two identical units of a good or offers the same homogenous service at different prices either to two different customers or to the same customer (Miravete, 2005). It was only possible if the seller provides similar products, charges different prices at different markets.

\subsection{Effect of Average Collection Period on Profitability of the Firm}

A study conducted by Mbula, Memba and Njeru (2016) on effect of accounts receivable on financial performance of firms funded by government venture capital in Kenya shows that there was a positive relationship between accounts receivables and financial performance of firms funded by government venture capital in Kenya.

A study conducted by Ikechukwu and Nwakaego (2015) on effect of accounts receivable management on profitability of Building Material/Chemicals and paint companies in Nigeria found out that accounts receivable had positive and significant effect on profitability, while debt ratio and sales growth rate had negative and nonsignificant effect on the profitability of Building Material/Chemicals and paint companies listed in Nigeria stock exchange.

Lazaridis and Tryfonidis (2006) found a negative relationship between number of day's accounts receivables and profitability measured by gross operating profit. This negative result demonstrated that companies can increase their profitability by decreasing credit term giving to their customers.

Deloof (2003) found a significant negative relationship between the average number of days accounts receivable and gross operating income as a measure of profitability. 
Boisjoly (2009) provide the evidence that companies had focused on improving the management of accounts receivable as their accounts receivable turnover increase over the 15 year time period for 1990-2004. Several techniques can be applied such as strengthen their collection procedures, offer cash discount and trade credit, and use receivables factoring (Boisjoly, 2009).

Samiloglu and Demirgunes (2008) conducted a study to examine the effect of working capital management on company profitability of listed manufacturing companies in Istanbul Stock Exchange for the period from 1998 to 2007. Cash conversion cycle, accounts receivable period and inventory period were used to measure the effects of working capital management; return on assets was used as a profitability measure. Results from regression analysis show that profitability had a significant negative relation with accounts receivable period.

Raheman and Nasr (2007) results reported that profitability had significant negative relationship with accounts receivable as a measure of liquidity. Furthermore, there was a negative relationship between average collection period and profitability found by (Alipour, 2011).

Mubashir (2012) did a study on determinants of accounts receivable and accounts payable management policies in Pakistan textile sector, the researcher found that accounts receivable were affected by the firms incentive to use credit as a means of price discrimination and a level of internal financing. The study also observed that the size of the firm also affected the level of accounts receivable that a firm maintains.

Ramchandran, and Janakiraman (2009) analyzed the relationship between working efficiency and earnings before interest and tax of the paper Industry in Indian. The study revealed that cash conversion cycle and inventory days had negative correlation with earnings before interest and tax, while accounts payable days and accounts receivable days related positively with earnings before interest and tax.

Research studied by Deloof (2003) Laziridis and Tryfonidis (2006) Garcia-Jeruel and Martinez Solano (2007), Samiloglu and Demrigunes (2008), in Belgium, Greece, U.S.A, Spain and turkey respectively, all point out to a negative relation between accounts receivable and firm profitability. Contradicting evidence was found by Sharma and Kumar. (2011) who found a positive relation between ROA and accounts receivable.

Mathuva (2010) in his study on the influence of working capital management on corporate profitability found that there exists a highly significant negative relationship between the time it takes for firms to collect cash from their customers and profitability

Samiloglu and Demirgunes (2008) analyzed the effect of working capital management on firm profitability in Turkey for a period of 1998-2007. Empirical results showed that, accounts receivables period, inventory turnover period and leverage significantly and negatively affected profitability. They also proved that cash conversion cycle, size and fixed financial assets had no statistically significant effect on profitability

A study conducted by Makori (2013) on Working Capital Management and Firm Profitability on Manufacturing and Construction Firms Listed on Nairob Securities Exchange in Kenya, the study found out existence of negative correlation between Return on Assets and the firms average collection period and cash conversion cycle. The result suggest that managers can create value for their shareholders by reducing the number of day's accounts receivable and increasing the accounts payment period and inventories to a reasonable maximum.

García-Teruel and Martínez-Solano (2007 examined effects of working capital management on profitability of 8,872 small and medium enterprises (SMEs) in Spain for the period from 1996 to 2002 . The return on assets (ROA) was used as a measure of profitability, and the number of days accounts receivable, number of days inventories, number of days accounts payable and cash conversion cycle are used to measure working capital management. The correlation matrixes demonstrates that the return on assets had the significant negative relationship with number of day's accounts receivable.

\subsection{Methodology}

Explanatory study design was adopted for the sudy. The target population of the study was 48 employees in charge of AR in four regions of NZOWASCO Kitale, Bungoma, Webuye and Kimilili. The study employed a census method where all 48 employees in charge of accounts were considered. Descriptive statistics and inferential statistics were used. The financial performance of Nzoia Water Services Company was measured in terms of average collection period

\subsection{Findings and Results}

Table 1: Financial Performance Statistic Results

\begin{tabular}{cccccc}
\multicolumn{5}{c}{ Descriptive Statistics } \\
\hline Variable & $\mathrm{N}$ & $\begin{array}{c}\text { Minim } \\
\text { um }\end{array}$ & $\begin{array}{c}\text { Maximu } \\
\mathrm{m}\end{array}$ & Mean & $\begin{array}{c}\text { Std. } \\
\text { Deviation }\end{array}$ \\
\hline ACP & 20 & 125 & 455 & 309.90 & 74.646 \\
\hline
\end{tabular}

Source; Research Data (2018)

The results in Table 1 shows the financial performance statistics of all the studied variables where the information about number of observation, mean, its dispersion as well as variability in the data was provided. From the findings the mean of average collection period was (309.90 days) and maximum number of days being (455 days) while minimum number of days was (125 days) the standard deviation among the regions was 74.646 which indicated a wide variation in the number of days in average collection period among the regions 
Table 2: Correlation between ACP and ROE

\begin{tabular}{|c|c|c|c|}
\hline & & PROF & $\mathrm{ACP}$ \\
\hline \multirow{3}{*}{ PROF } & $\begin{array}{c}\text { Pearson } \\
\text { Correlation }\end{array}$ & 1 & -.232 \\
\hline & Sig. (2-tailed) & & .324 \\
\hline & $\mathrm{N}$ & 20 & 20 \\
\hline \multirow{3}{*}{$\mathrm{ACP}$} & $\begin{array}{c}\text { Pearson } \\
\text { Correlation }\end{array}$ & -.232 & 1 \\
\hline & Sig. (2-tailed) & .324 & \\
\hline & $\mathrm{N}$ & 20 & 20 \\
\hline
\end{tabular}

The results in Table 2 show the correlation analysis among the firms 'financial performance variables. The result shows that Nzoia Water Services Company's financial performance variable, return on equity (ROE) was not significantly affected negatively by Average collection period with a negative $(r=-0.232 ; \rho>0.324)$ with ROE indicating $23.20 \%$ negative relationship with profitability. This means that ACP contributes a negative of $23.20 \%$ reduction in $\mathrm{ROE}$. The study agrees with findings by Mohammadi (2009) who showed that there exists inverse association between conversion period of trade receivables, cash conversion cycle, inventories and profitability among firms listed at Tehran Stock Exchange between 1996 and 2005. The study findings further agree with findings from Deloof (2003) who documented that there exists negative relationship between profitability and the number of days accounts receivable take to be collected. This is consistent to the fact that less profitable firms wait longer to settle their bills and shorter time to collect their debt. This study further supports the findings of Smith \& Begemann (1997) who revealed that profitability and liquidity work in different reverse directions. However, this study contradicts with findings by Lazaridis and Tryfonidis (2006) who discovered that there exist significant association between profitability and cash conversion cycle of firms listed at Athen stock exchange. Firms record high profitability level by keeping the cash conversion cycle at its optimum levels. This study had however established that the association was not significant.

Table 3: Model summary of ACP and the financial performance

\begin{tabular}{ccccc}
\multicolumn{5}{c}{ Model Summary } \\
\hline $\begin{array}{c}\text { Mo } \\
\text { del }\end{array}$ & $\mathrm{R}$ & $\mathrm{R}$ & $\begin{array}{c}\text { Adjusted } \\
\text { R Square }\end{array}$ & Std. Error of the Estimate \\
\hline 1 & $.232^{\mathrm{a}}$ & .054 & .001 & .0216848 \\
\hline
\end{tabular}

a. Predictors: (Constant), ACP

Table 3 Provides the $R$ and $R 2$ values which represent the data correlation. The ( $R$ Squared) indicates that the coefficient of determination ( $R$ squared) was 0.054 which implies that $5.4 \%$ of the changes in ROE is explained by the ACP variable while the other $94.5 \% \%$ of the variation is explained by other factors.
Table 4: ANOVA for ACP and Financial performance

\begin{tabular}{ccccccc}
\hline \multicolumn{7}{c}{ ANOVA for ACP and Financial performance } \\
\hline \multirow{2}{*}{ Model } & $\begin{array}{c}\text { Sum of } \\
\text { Squares }\end{array}$ & Df & $\begin{array}{c}\text { Mean } \\
\text { Square }\end{array}$ & F & Sig. \\
\hline \multirow{4}{*}{1} & Regression & .000 & 1 & .000 & 1.026 & .324 \\
& Residual & .008 & 18 & .000 & & \\
& Total & .009 & 19 & & & \\
\hline \multicolumn{7}{c}{ a. Dependent Variable: ROE } \\
& b. Predictors: (Constant), ACP & &
\end{tabular}

The hypotheses formulated for this study were tested in this section using the t-values produced by the SPSS output shown in table 4 . The level of significance for the study is $5 \%$ (two-tailed test). Therefore, the critical value for $t$ is \pm 1.96 . The decision rule for this test is to accept (or reject) the null hypothesis if the critical value is greater (or less) than the calculated $t$ value shown in the SPSS output of table 4.The hypotheses are tested in this as follows:

\section{$\mathbf{H}_{01}$ : There is no significant relationship between Average Collection Period and financial performance of NZOWASCO}

Table 4 Provides results for the testing of this null hypothesis (Ho1) above. The result shows that the calculated value of $t$ for ACP is 1.026. Therefore, the critical value (1.96) is greater than the calculated value of t for ACP as shown in table 4. Thus, the null hypothesis is accepted and it is concluded that the profitability of NZOWASCO is not significantly influenced by ACP. This position is confirmed when the level of significance for this study (0.05) is compared with the significant level (sig) of ACP (0.324) as shown in table 4

\subsection{Summary, Conclusion and Recommendations}

The first objective of the study was to determine the effect of average collection period on the financial performance of Nzoia water Services company. The study reveals that $A C P$ is not a significant determinant of ROE. Findings revealed that ACP was negatively and insignificantly associated with ROE ( $r=-0.232 ; \rho>0.324)$ indicating $23.20 \%$ negative relationship with profitability. Correlation tests and panel data analysis through the fixed effects model revealed that there was no association between ACP and ROE. It would be expected that companies with less ACP would be efficient in cash conversion and hence be more profitable.

Average collection period was found to be statistically insignificant and had negative relationship with (profitability) return on equity, indicating that if time period of average collection period is reduced then overall financial performance in liquidity of Nzoia Water services Company improves.

The study found out that accounts receivables have an insignificant effect on the (profitability) return on Equity of Nzoia water Services Company. Accounts receivables is therefore used as source of financing, to boost sales and 
growth. Firms should institute proper accounts receivables policies to control its level of sales on credit since it is classified as the second level of current assets.

\subsection{Recommendations}

The study recommended that Nzoia Water services Company should reduce its average collection period in order to improve their financial performance. In order to improve their financial performance there is need to reduce the average collection period currently present.

From the results of the study, it was recommended that the management of NZOWASCO should put in place a very vibrant credit policy so as to help avoid poor account receivables. The monitoring and collections team should also be empowered and well equipped to enable them carry out their responsibility of recovering the debts for the company. Management of NZOWASCO should also be given targets to meet when it comes to account receivables in particular and employees should be awarded or sanctioned appropriately when they fail to achieve their targets. NZOWASCO should also introduce the prepaid system in their operations to reduce the number of account receivables they usually incur from their customers.

\section{References}

[1]. Adembo, A. C. (2014). Effect of trade receivable on profitability of manufacturing and allied firms listed at Nairobi securities exchange.

[2]. Ahmet, G. S., \& Emin, H. C. (2012). Effects of working capital management on firms performance. International Journal of Economics and Financial Issues, 2(4), pp 488-495.

[3]. Akbas, \& Karaduman. (2012). Effect of firm size on profitabilityof firms operating in manufacturing sector ,listed in ISE. European Journal of Economics, Finance and Administrative Sciences, 2(2), pp 47-54.

[4]. Alipour. (2011). Effect of working capital management practices on financial performance of small scale enterprises in Kisii Kenya.

[5]. AL-Mwala, M. (2012). The impact of working capital management policies on firm profitability and value. The case jordan. International Research Journal of Finance and Economics., 85, pp 1-9.

[6]. Ammar, A., S.Hanna, A., Nordheim, E. .., \& Russel, J. S. (2003). Indicator Variables. Journal of Construction Engineering and Management.

[7]. Ansah, S. O. (2011). An assesment of working capital management practices within Ghana water company limited.

[8]. Backman, T. (1962). Credit and Collection Management and Theory. New York.

[9]. Boisjoly, R. (2009). The cash flow implications of managing working capital and capital investment. Journal of Business and Economics Studies.

[10]. Borg, W. R., \& Gall, M. D. (1986). Educational Research and Introduction,. New York.

[11]. Chi, j. (2004). Understanding the endogeneity between firm value and shareholders rights. Financial Management, 465417.
[12].Cooper, D., \& Schindler, P. (2006). Business Research Methods: Empirical investigation. Journal of service Research, 1(2).

[13]. Deloof, M. (2003). Does Working capital Management Affect Profitability of Belgian Firms. Journal of Business Finance \& Accounting.

[14]. Demirgunes, \& Samiloglu. (2008). Effect of working capital management on firm profitability in Turkey for a period of 1998-2007.

[15].Dogan. (2013). The impact of size, age, liquidity and leverageon profitability for 200 companies listed in I stanbul stock exchange. Research Journal of Accounting and Finance, 4(4).

[16]. Ehi-Oshio. (2013). Determinants of corporateprofitabilityin developing economies. European Journal of Business and Management, 5(16).

[17]. Ezejiofor, A. R. (2015). The credit management on liquidity and profitability positions of manufacturing company in Nigeria. Europeen journal of research and reflectionin management science, 3(3).

[18]. Feris, J. (1981). A transaction theory of trade credit use. The quarterly journal of the financial Review, 96(2), pp 243247.

[19]. Foulks, I. (2005). Financial Management and Control. London: FTC Fouls Lynch.

[20]. Fraenkel, J., \& Wallen, N. (2000). How to design and evaluate Research in Education. New York: McGraw Hill Publishing Company.

[21]. Francis, \& Taylor. (n.d.). Strategy: Critical persepective on Business Management. Amazon.

[22]. Garcia, T., \& Martinez, S. (2007). effects of working capital managementon profitability of 8,872 small and medium enterprises (SMEs) in Spain. International journal of management finance, 3, pp 164- 177.

[23]. Gedajlovic, E., \& Shapiro, D. M. (1998). Management and ownership effects: Evidence from five, countries. Strategic Management, 19, 533-553.

[24]. Ghafoorifardi, M. (2014). The relationship between firm size, age and Financial performance. International Journal of Scientific Management and Development.

[25]. Gill, A., Bigger, N., \& Atnur, C. (2010). The Relationship between working capital management and profitability. Business and Economic Journal.

[26].Gill, J., \& Johnson, P. (2010). Research methods for managers.

[27]. Gitau, B. N., Nyangweno, G., Mwencha, N., \& Onchagwa, G. A. (2014). Influence of cash management practices on Financial Performance of Agribusiness Enterprises in Kenya. International Journal of Social Studies and Enterprises, $1(12)$.

[28]. Ifurueze, M. S. (2013). The Impact of effective management of credit sales on profitability and liquidity of food and beverage industries in Nigeria. Global journal of mangement and business research, 13(2).

[29]. Ikechukwu, I. O., \& Nwakaego, A. D. (2015). The Effect of Receivable Management on the Profitability of Building Materials/Chemical and Paint Manufacturing Firms In Nigeria. Journal of Research in Humanities and Social Science, 3(10), pp 01-06.

[30].Joy, M. O. (1978). Introduction to Financial Management. (Madras :Institute for Financial Management and Research) New Delhi, pp 210.

[31]. Kabiru, N., \& Kalunda, J. (2012). Pharmaceutical manufacturing companies in Kenya and their credit risk 
management. Research journal of Finance and Auditing., 3(4), pp 159-167.

[32]. Kakuru, J. (2000). Financial Decisions and the business(. The business publishing group Kampala.

[33]. Keown, J. A., Martin, H. J., Petty, W. J., \& Scott, F. D. (2002). Financial Management: (10th ed.). Principles and Applications.

[34]. Kilonzo, J. M., Memba, S. F., \& Njeru, A. (2016). Effect of Accounts Receivable on Financial Performance of Firms Funded By Government Venture Capital in Kenya. Journal of Economics and Finance, 7(1), pp 62-69.

[35]. Kimani, J. W. (2013). Principles and practice of effective accounts management in Kenya.

[36]. Kipesha. (2013). The impact of size, age on firm performance in Tanzania Microfinance Institutions. Research Journal of Finance and Accounting, 4(5), pp 105116.

[37]. Kontus, M. S. (2013). Management of accounts receivable.

[38]. Kontuš, M. S. (2013). Management of accounts receivable. Kastav.

[39]. Kothari, R. C. (2004). Research Methods, Methods and Techniques. ISBN: New Age limited.

[40]. Lantz, B. (2008). Operative verksamhetsstrnig.

[41]. Makori, D. (2013). working capital management and firm profitability on manufacturing and construction firms listedon Nairobi Securities Exchange in kenya.

[42]. Maksimovic, V., \& Demirguc, A. K. (2001). Firms as Financial Intermediaries: Evidence from Trade Credit Data. World Bank Working Paper 26256

[43]. Management and ownership and effects: Evidence from five, countries. (1998). E R Gedajlovic; D M Shapiro(19), 533-553.

[44]. Mbula, J. K., Memba, S., \& Njeru, A. (2016). Effect of Accounts Receivable on Financial Performance of Firms Funded By Government Venture Capital in Kenya. IOSR Journal of Economics and Finance.

[45]. Miravete, E. (2005). Competitive nonlinear pricing in duopoly equilibrium: the early U.S. cellular telephone industry. Discussion Paper No. 4069. London: CEPR

[46]. Mohammadi, M. (2009). Effects of Working Capital Management on Companies' Profitability of Listed Companies on Tehran Stock Exchange. Journal of Management, 14, 80-251

[47]. Morrison, R. G., Ross, M. S., \& Kemp, E. J. (2007). Designing Effective Instruction (5th $\mathrm{Ed}$ ). Hoboken: NJ:Jossey-Bass.

[48]. Mubashir. (2012). Determinants of accounts receivable and accounts payable management policies in Pakistan textile sector.
[49]. Mugenda, \& Mugenda. (1999). Research Methods Quantitative and Qualitative Approaches. Acts press.

[50]. Mugenda, M., \& Mugenda, G. (2008). Resaerch Methods: quantitative and qualitative. Nairobi: Acts press.

[51]. Mumma, A. ((January 26-28 2005)). Kenyas new water law: An analysis of the Implications for the Rural Poor. Paper presented at the international workshop on" Africa water laws: Plural legislative frameworks for rural water management in Africa".

[52]. Nasr, \& Raheman. (2007). Effect of accounts receivable on firm profitability.

[53]. Niresh, \& Velnampy. (2014). Effect of size of a firm on profitability of quoted manufacturingfirms in Sri lanka. International Journal of Business and Management, 9(4).

[54]. Obida, S., \& Owolabi, S. (2012). Liquidity Management and Corporate Profitability: Case Study of Selected Manufacturing Companies Listed on the Nigerian Stock Exchange. Journal of Business Management,

[55]. Pandey, I. M. (2008). Financial Management. New Delhi: Viker publishing House.

[56]. Panwala, W. (2009). Dimensions of Liquidity Management. National Journal of System and Information Technology, 2(1), pp 117-126.

[57]. Periassamy, P. (2009). Financial management. MCGrawHill Publications.

[58]. Petersen, M., \& Rajan, R. (1997). Trade Credit: Theories and evidence. The review of financial studies, 10(3), pp 661669.

[59]. Ramachandran, A., \& Janakiraraman, M. (2009). The Relationship between working capital management efficiency and EBIT. managing global transitions, Vol. 7 (1) 61-74, 7(1), 61-74

[60].Schwartz, K. (2007). The new public management. The future for reforms in the African Water Supply and Sanitation Sector? Utilities Policy.

[61].Serrasqueiro, Z. (2009). Growth and profitability in Portuguese companies. Economic Interferences, Serrasqueiro, Z. (2009)

[62].Smith, M., \& Begemann, E. (1997). Measuring Association between Working Capital and Return on Investment. South African Journal of Business Management, 28.

[63].Sounders, M., Lewis, P., \& Thornhill, A. (2009). Research methods for business students (3rd Ed). Harlow: Prentice Hall.

[64]. W, K. J. (2013). Principles and practice of effective accounts receivable in Kenya.

[65]. WASREB, \& WSP. (2015). Kenya Water Service Provider Creditworthiness Index Report November 2015. WORLD BANK GROUP.

[66].Yi, C., \& Tzu, H. (2005). The relationship between multinationality and the performance of taiwan firms. The Journal of American Academy of Business., 6(1), 130-134. 